\title{
Penerapan Full Day School Terhadap Pembinaan Akhlakul Karimah Siswa
}

\author{
Miftahul Aula Sa’adah', Mahmudah² \\ 1UIN Antasari, Kota Banjarmasin, Indonesia \\ Email bundabangzhafran@gmail.com \\ 2UIN Antasari, Kota Banjarmasin, Indonesia \\ Emailniemoedza@gmail.com
}

\begin{abstract}
ABSTRAK
Penanaman dan pembinaan akhlak di sekolah menjadi hal yang sangat dibutuhkan, karena kemajuan dalam bidang ilmu pengetahuan dan teknologi memberikan dampak positif dan negatif bagi perkembangan siswa. Saat ini kemerosotan moral yang dilakukan oleh siswa menimbulkan keresahan bagi keluarga, sekolah dan masyarakat. Melalui program full day school, diharapkan sekolah tidak hanya menjadi wadah transfer ilmu pengetahuan tetapi juga sebagai wadah dalam pembinaan akhlak karimah bagi siswa. Pendekatan yang digunakan dalam penelitian ini yaitu penelitian lapangan (field research). Teknik pengumpulan data melalui observasi, wawancara, dan dokumentasi. Kemudian data diolah dengan menggunakan pendekatan analisis deskriptif kualitatif. Hasil yang diperoleh dalam penelitian ini menunjukkan bahwa penerapan full day school terhadap pembinaan akhlakul karimah siswa di SMAIT Ukhuwah Banjarmasin dilaksanakan melalui kegiatan intrakurikuler dan kegiatan ekstrakurikuler. Kegiatan intrakurikuler dilaksanakan melalui proses belajar mengajar dan bina pribadi islami. Adapun kegiatan ekstrakulikuler meliputi pramuka, olahraga dan seni, dan tarhib Ramadhan. Faktor pendukung dalam pembentukan akhlak siswa adalah adalah kurikulum yang sesuai dengan integrasi nilai-nilai keislaman, sumber daya manusia yang berkualitas, fasilitas sarana prasarana yang mendukung, dan keterlibatan aktif serta dukungan dari orang tua siswa. Adapun faktor penghambat pelaksanaannya adalah faktor lingkungan siswa dan faktor pendanaan.

Kata Kunci: Pembinaan Akhlakul Karimah; Penerapan Full Day School; Siswa.
\end{abstract}

\begin{abstract}
Cultivation and guidance morals in schools is very necessary, because progress in the field of science and technology has a positive and negative impact on student development. Nowadays moral decline by students raises unrest for families, schools and communities. Through the full day school program, it is hoped that the school will not only become a place for transfer of knowledge but also as a forum for guidancing morality for students. The approach used in this research is field research. Data collection techniques through observation, interviews, and documentation. Then the data is processed using a qualitative descriptive analysis approach. The results obtained in this study indicate that the application of full day school to the development of students' morality in
\end{abstract}


SMA Ukhuwah Banjarmasin is carried out through intracuricular activities and extracurricular activities. Intracuricular activities are carried out through teaching and learning processes and Islamic personal development. The extracurricular activities include scouting, sports and arts, and Ramadhan tarhib. Supporting factors in the formation of student morals are a curriculum that is compatible with the integration of Islamic values, quality human resources, supporting infrastructure facilities, and active involvement and support from parents of students. The inhibiting factors are the students' environmental factors and funding factors.

Keywords : Fostering Akhlakul Karimah, Application Full Day School, Student

Article history:

Received: 26-09-2019

Revised: 07-02-2020

Accepted: 27-02-2020

\section{PENDAhUluan}

Agama Islam sangat menjunjung tinggi penerapan etika dan akhlak dalam kehidupan sehari-hari, karena akhlak merupakan tingkah laku, perangai, tabiat dan karakter setiap manusia baik maupun buruk yang berhubungan langsung antara manusia dengan Allah, hubungan manusia dengan sesama manusia dan hubungan manusia dengan lingkungan (Rokayah, 2015: 15).

Penerapan dan pembinaan akhlak menurut pandangan Islam terintegrasi dengan pelaksanaan rukun Islam. Hasil analisis Muhammad Al-Ghazali menyatakan bahwa dalam rukun Islam terdapat konsep pembinaan akhlak. Rukun Islam yang pertama adalah mengucapkan dua kalimat 2 syahadat, kalimat ini mengandung pernyataan bahwa hidup manusia hanya tunduk dan patuh kepada aturan dan tuntunan Allah. Rukun Islam kedua yaitu melaksanakan shalat lima waktu. Shalat yang dilaksanakan akan membawa pelakunya terhindar dari perbuatan keji dan mungkar. Rukun Islam ketiga yaitu mengeluarkan zakat juga mengandung konsep pendidikan akhlak, yaitu orang yang mengeluarkan zakat dapat membersihkan dirinya dari sifat kikir, mementingkan diri sendiri, dan membersihkan hartanya dari hak orang lain, yaitu hak fakir miskin dan seterusnya. Rukun Islam keempat yaitu melaksanakan puasa, bukan sekedar menahan diri dari makan dan minum tetapi latihan menahan diri dari keinginan 
melakukan perbuatan keji yang tidak dianjurkan dalam agama. Rukun Islam kelima yaitu menunaikan ibadah haji bagi yang mampu. Pelaksanaan ibadah haji terdapat nilai pembinaan akhlak yang lebih besar dibandingkan dengan nilai pembinaan akhlak pada ibadah lain dalam rukun Islam. Hal ini dikarenakan ibadah haji dalam Islam bersifat menyeluruh yaitu menuntut persyaratan yang banyak, disamping harus menguasai ilmu, sehat secara fisik, adanya kemauan, sabar dan lain sebagainya (Nata, 2010: 160-163).

Akhlak dalam perspektif Islam menempati posisi yang penting sehingga setiap aspek diajarkan berorientasi terhadap pembentukan dan pembinaan akhlakul karimah. Salah satu

cara mengimplementasikan nilai-nilai akhlak melalui pendidikan. Pendidikan dirancang sedemikian rupa agar peserta didik dapat memahami, menghayati dan mengamalkan nilai-nilai akhlakul karimah. Pendidikan adalah suatu upaya untuk menambah kecakapan, keterampilan, pengertian dan sikap melalui belajar dan pengalaman yang dibutuhkan manusia untuk mempertahankan dan melangsungkan kehidupan serta usaha untuk mencapai tujuan hidupnya. Usaha itu terdapat baik dalam masyarakat yang sudah maju, maupun yang sangat maju (Mappanganro, 1996: 9).

Penerapan nilai-nilai akhlak di sekolah sangat penting mengingat perkembangan zaman, kemajuan ilmu pengetahuan dan teknologi yang diikuti dengan dampak positif dan negatif. Adapun dampak negatif seperti fenomena kesenjangan sosial, seperti bullying, tawuran dan perkelahian antar pelajar, minumminuman keras, konsumsi obatobatan terlarang dan lain-lain.

Penyebab timbulnya perilaku menyimpang yang dilakukan oleh remaja dikarenakan berbagai faktor, yaitu (a) lemahnya pegangan terhadap agama, percaya bahwa Allah itu ada tetapi melanggar larangan-larangan agama; (b) tidak efektifnya pembinaan moral yang dilakukan, baik dalam lingkungan keluarga, sekolah dan masyarakat; (c) kuatnya budaya matrealisme, hedonisme, dan sekularisme; (d) belum optimalnya pembinaan moral 
bangsa yang dilakukan oleh

Menurut Arifin (2012: 107), pemerintah (Nata, 2007: 191-194).

Sampai saat ini pendidikan agama yang berlangsung di sekolah masih lemah. Pendidikan agama yang dilaksanakan di sekolah masih mengalami kegagalan yang disebabkan karena praktek pendidikan Islam hanya mempertimbangkan aspek kognitif dari pertumbuhan kesadaran nilainilai agama dan mengabaikan pembinaan aspek afektif maupun aspek non afektif yaitu kemauan dan tekad dalam mengamalkan nilai-nilai ajaran Islam (Muhaimin, 2009: 23).

Proses pembentukan akhlak pada anak harus dilakukan secara intens dan dilakukan dengan memelihara perilaku-perilaku positif yang sudah menetap agar tidak berubah lagi. Akhlak setiap manusia tidak terbentuk dengan sendirinya, akan tetapi melewati berbagai proses pembentukan yang cukup panjang selama hidupnya. Salah satu strategi dalam membentuk akhlak karimah pada anak yaitu melalui pendidikan yang berkualitas terutama pendidikan yang berbasis agama, sebagai pondasi utama. sistem full day school adalah ciri khas sekolah terpadu yang mana proses pembelajaran dilaksanakan sejak pagi hingga sore hari. Program pendidikan di sekolah full day school dirancang dengan memadukan proses pembelajaran dan kegiatan tambahan yang bernuansa agamis siswa diberikan waktu tambahan untuk lebih mendalami pelajaran keagamaan.

Menurut Sulistyaningsih (2008: 65), full day school adalah model sekolah umum yang dipadukan dengan pembelajaran agama secara intensif yang deprogram secara khusus diberikan kepada siswa untuk mendapatkan pemahaman keagamaan yang lebih mendalam. Tujuan pelaksanaan pendidikan sistem full day school untuk meningkatkan potensi positif, kreativitas, bakat dan minat siswa baik secara kognitif, afektif maupun psikomotorik, dengan memberikan kegiatan tambahan intrakurikuler maupun ektrakurikuler yang di programkan oleh sekolah.

Sekolah Islam Terpadu Ukhuwah memiliki 6 lembaga pendidikan di dalamnya, yaitu PAUDIT, SDIT, SMPIT, SMAIT, 
Madrasah Tahfizh, dan SMPIT

Penelitian ini menggunakan Hidayatul Quran Boarding School. Lembaga pendidikan Sekolah Islam Terpadu Ukhuwah tersebut memiliki prestasinya masingmasing. Sekolah Islam Terpadu Ukhuwah telah banyak mendapatkan penghargaan melalui prestasi akademik peserta didiknya, prestasi pihak sekolah dalam meluluskan peserta didik dengan predikat terbaik, dan terakreditasi A untuk PAUD, SDIT, SMPIT, dan SMAIT. Mengingat bahwa SMAIT Ukhuwah adalah sekolah berbasis Islam yang unggul dan bermutu, hal ini tidak terlepas dari peran sekolah dengan bimbingan serta pembinaan yang tepat dengan mengarahkan seluruh dewan guru untuk ikut andil dan berusaha dalam membantu pembentukan akhlak siswa menjadi pribadi muslim yang berakhlak mulia.

Berkaitan dengan paparan latar belakang masalah di atas, peneliti tertarik dalam melakukan penelitian yang berjudul

"Penerapan Full Day School dalam Pembinaan Akhlakul Karimah".

\section{METODE PENELITIAN} jenis penelitian lapangan (field research) karena dikonsentrasikan untuk menjelaskan kenyataankenyataan di lapangan. Adapun jenis pendekatan yang digunakan dalam penelitian ini adalah pendekatan deskriptif kualitatif yang bersifat menggambarkan kenyataan di lapangan.

Subjek dalam penelitian adalah satu orang kepala sekolah, satu orang guru Pendidikan Agama Islam, dan siswa di SMAIT Ukhuwah Banjarmasin. Adapun objek dalam penelitian ini adalah penerapan full day school dalam pembinaan akhlakul karimah dan faktor pendukung dan penghambat penerapan full day school dalam pembinaan akhlakul karimah. Pengumpulan data menggunakan teknik observasi, wawancara, dan dokumentasi.

\section{HASIL PENELITIAN DAN PEMBAHASAN}

1. Penerapan Full day school dalam Pembinaan Akhlakul Karimah.

a. Kegiatan Intrakurikuler Berdasarkan penyajian data di atas, kegiatan intrakurikuler di SMAIT Ukhuwah Banjarmasin 
dilaksanakan pada hari Senin sampai Jum'at dimulai jam 07.30-16.30 WITA. Siswa datang ke sekolah dalam keadaan thaharah (suci dan sudah berwudhu), sekolah sangat mendukung proses pembentukan akhlak siswa dengan memisah ruang kelas dan tangga berdasarkan jenis kelamin sehingga wudhu tetap terjaga.

\section{1) Proses Belajar Mengajar} (PBM)

Proses belajar mengajar yang dilaksanakan di kelas diawali dengan pengecekan amal yaumiy siswa. Melalui amal yaumiy, siswa dibiasakan dengan berbagai ibadah amaliah seperti sholat wajib 5 waktu, sholat sunnah, dan sedekah. Kelas dilanjutkan dengan murojaah, dan berdoa bersama sebelum pembelajaran dimulai agar siswa terbiasa selalu berdoa sebelum melakukan kegiatan. Kurikulum yang diterapkan di SMAIT Ukhuwah Banjarmasin sangat mendukung terlaksananya full day school dalam pembinaan akhlakul karimah siswa dengan mengimplementasikan nilainilai keislaman pada setiap proses pembelajaran. Setiap penyampaian mata pelajaran dilengkapi dengan muatan religius keislaman yang membuat siswa tidak hanya mengetahui materi pembelajaran tetapi juga memahami dan menghayati nilai-nilai Islam yang terdapat dalam materi pembelajaran sehingga mudah diterapkan oleh siswa dalam kehidupan sehari-hari.

Berdasarkan penyajian data di atas, guru di SMAIT Ukhuwah Banjarmasin selalu berusaha memberikan pembelajaran secara maksimal dengan menggunakan beberapa metode dan games yang bervariasi sehingga siswa belajar merasa senang dan tidak merasa bosan dengan penerapan full day school di sekolah, selain itu juga didukung oleh manajemen sekolah yang baik dengan diadakannya berbagai pelatihan untuk guru oleh Yayasan Ukhuwah. 
Pembinaan akhlak siswa di SMAIT Ukhuwah Banjarmasin dilakukan dengan berbagai cara atau metode, seperti metode pembiasaan, metode contoh/keteladanan, dan metode pemberian nasehat. Melalui metode pembiasaan, siswa menjadi terbiasa melakukan hal-hal positif yang dibiasakan oleh pihak sekolah; melalui motode keteladanan, siswa melihat, mencontoh dan meniru perilaku-perilaku positif; melalui metode pemberian nasihat, siswa terhindar dari melakukan halhal yang bersifat negatif dan selalu berupaya mengerjakan hal-hal yang bersifat positif.

Untuk membentuk manusia yang berakhlak mulia dalam pendidikan Islam dapat dilakukan melalui berbagai macam metode. Beberapa metode terdapat dalam ayatayat Al-Quran, seperti mendidik melalui percakapan (hiwar) Qurani dan Nabawi, mendidik melalui kisah-kisah Qur'ani dan Nabawi, mendidik melalui perumpamaan, mendidik dengan keteladanan, mendidik melalui pengamalan dan latihan, mendidik melalui ibrah dan mau idhah serta mendidik melalui targhib dan tarhib (Hidayat, 2015: 149).

Berdasarkan hasil penyajian data di SMAIT Ukhuwah bentuk pembiasaan tersebut antara lain; menjaga wudhu, murojaah hafalan, shalat dhuha, shalat berjamaah, shalat qabliyah dan ba'diyah, berpuasa ayyamul bidh, mengetuk pintu serta ketika masuk kelas harus mengucapkan salam terlebih dahulu, membiasakan sebelum dan sesudah pembelajaran berdoa terlebih dahulu, menjaga kebersihan, membuang sampah pada tempatnya, makan dan minum dengan adab yang baik, berpakaian rapi serta menutup aurat, bersikap sopan santun dan berkata yang lemah lembut. Menurut Arief (2002: 110), metode pembiasaan merupakan strategi yang dapat dilakukan oleh guru untuk membiasakan siswa berpikir, bersikap dan bertindak sesuai dengan anjuran ajaran agama 
Islam. Sedangkan Daryanto (2013: 43) mengemukakan penerapan akhlakul karimah menekankan pada habit atau metode pembiasaan yang terus menerus dilaksanakan atau dipraktekkan.

Metode keteladanan dalam bidang pendidikan merupakan salah satu metode yang efektif dalam mempersiapkan dan membentuk peserta didik baik secara spiritual, sosial dan moral. Hal ini disebabkan seorang pendidik bagi setiap peserta didik merupakan panutan atau contoh ideal, yang mana perilaku dan sikap sopan santunnya selalu ditiru, baik itu disadari ataupun tidak keteladanan itu akan menetap pada diri dan perasaannya, baik dari segi ucapan, perbuatan, hal-hal yang bersifat inderawi, material dan spiritual (Manan. 2017: 53). Berdasarkan hasil penyajian data di SMAIT Ukhuwah, bentuk metode keteladanan yang dicontohkan guru seperti berpakaian rapi serta menutup aurat, melaksanakan shalat sunnah dan wajib, berpuasa ayyamul bidh, berbicara dengan lemah lembut, dan sopan santun. Menurut Arief (2002: 90), keteladanan dalam terminologi Al-Quran disebutkan dengan istilah 'Uswah' dan 'Iswah' atau dengan kata lain 'al-qudwah' dan al-qidwah, yang mempunyai arti suatu kondisi dimana seseorang mengikuti orang lain, apakah dalam aspek kebaikan ataupun kejelekan. Jadi, keteladanan adalah hal-hal yang dapat ditiru atau dapat dicontoh oleh individu dari orang lain. Tetapi keteladanan yang dimaksud adalah keteladanan yang dapat digunakan sebagai alat pendidikan Islam, yakni keteladanan yang baik sesuai dengan maksud dari 'uswatun hasanah.

Pemberian nasihat disampaikan dengan cara yang lemah lembut dan juga pada saat yang tepat, misalnya diselipkan ketika kegiatan belajar mengajar, dan waktu istirahat. Selain itu metode nasihat juga diberikan oleh guru ketika ada siswa yang 
melakukan pelanggaran tata tertib di sekolah. Nasihat diberikan agar timbul kesadaran dari peserta didik bahwa perilaku atau perbuatan yang mereka lakukan salah. Menurut Nata (2005: 152), secara eksplisit Al-Qur`an menggunakan metode nasihat sebagai salah satu cara yang dapat digunakan untuk menyampaikan isi ajaran AlQur`an. Al-Quraan menerangkan tentang penasihat, orang yang dinasihati, objek nasihat, situasi nasihat, dan latar belakang nasihat. Karena sebagai salah satu metode dalam pengajaran, maka nasihat dapat diakui kebenarannya.

2) Bina Pribadi Islam (BPI)

Berdasarkan penyajian data, dapat disimpulkan bahwa kegiatan Bina Pribadi Islami (BPI), seperti kegiatan mentoring/halaqah dan pembinaan adab yang dilaksanakan di SMAIT Ukhuwah Banjarmasin sudah berjalan dengan baik dan maksimal, guru selalu berusaha memberikan pembinaan terhadap akhlak siswa secara maksimal dengan melakukan kegiatan praktek yang menyenangkan, menggunakan berbagai metode yang bervariasi, dan memanfaatkan fasilitas, baik sarana maupun prasarana yang terdapat di sekolah. Kegiatan bina pribadi Islami adalah suatu kegiatan pendidikan dan pembinaan agama Islam yang dikemas dalam bentuk pengajian yang dibagi dalam beberapa kelompok kecil. Setiap kelompok terdapat ustadz atau ustadzah sebagai murabbi atau pembimbing dan terdapat siswa sebagai mutarabbi atau peserta. Bina pribadi Islami dilaksanakan secara rutin setiap pekan dan berkelanjutan. Kegiatan ini diharapkan dapat memaksimalkan

menyampaikan nasihat dan pembinaan akhlakul karimah dengan baik sehingga tercapai target pendidikan yaitu mengembangkan potensi siswa agar menjadi insan yang 
beriman dan bertakwa kepada Allah, memiliki akhlak mulia, sehat, memiliki ilmu pengetahuan, cakap, terampil, kreatif, mandiri dan menjadi warga negara yang demokratis serta bertanggung jawab.

b. Kegiatan Ekstrakurikuler

Berdasarkan penyajian data di atas, kegiatan tambahan dan ekstrakurikuler yang ada di SMAIT Ukhuwah Banjarmasin bertujuan membentuk insan yang memiliki ilmu pengetahuan dan bertaqwa kepada Allah, sesuai dengan visi misi sekolah yaitu membentuk peserta didik yang berakhlak, berprestasi, mandiri, dan berwawasan lingkungan. Kegiatan-kegitan yang sesuai dengan ajaran Islam akan meningkatkan kualitas iman dan taqwa siswa, sehingga kelak siswa akan dapat menjaga dan membentengi diri agar tidak mudah terpengaruh kepada halhal yang bersifat negatif yang datang dari luar.

\section{1) Pramuka}

Salah satu kegiatan pramuka yang ada di SMAIT Ukhuwah Banjarmasin yaitu berkemah di luar sekolah.
Program ini dilakukan pada semester ganjil untuk siswa putra dan semester genap untuk siswa putri. Siswa tidak hanya diajak sekedar berkemah, akan tetapi para pembina dan panitia mendesain selama kegiatan berkemah bertujuan untuk membentuk akhlak siswa. Pembentukan akhlak tersebut diantaranya yaitu akhlak kepada Allah yang diaplikasikan dalam shalat berjamaah, tilawah, dan qiyamul lail, akhlak terhadap sesama diwujudkan dengan berbagi sembako kepada masyarakat sekitar, dan akhlak terhadap lingkungan melalui pembersihan masjid atau musola di sekitar bumi perkemahan.

\section{2) Olahraga dan Seni}

Kegiatan olahraga dan seni seperti futsal dan tari tetap mengedepankan akhlak yang mulia kepada Allah seperti dalam hal berpakaian yang menutup aurat sebagaimana perintah agama Islam.

3) Kegiatan Tarhib Ramadhan 
Kerjasama orangtua di SMAIT Ukhuwah Banjarmasin yang siap mendukung program-program sekolah untuk siswa seperti menyumbang paket sembako untuk dibagikan kepada masyarakat sekitar sekolah sangat membantu terhadap proses pelaksanaan pembentukan akhlak siswa. Pada kegiatan ini, sekolah menanamkan akhlak tidak hanya akhlak kepada sesama melainkan juga terhadap akhlak kepada lingkungan. Siswa diajak untuk membersihkan masjid dan mushola di sekitar sekolah. Dengan demikian, siswa dapat mengamalkan materi yang diberikan guru pada kegiatan belajar mengajar sambil bersosialisasi kepada sesama. Di dalam ranah kegiatan ekstrakurikuler, pembentukan akhlak tidak keluar dari ruang lingkup pembahasan akhlak.

2. Faktor Pendukung dan Penghambat Penerapan Full Day School dalam Pembinaan Akhlakul Karimah a. Faktor Pendukung

1) Kurikulum

Kedudukan kurikulum sebagai rancangan pendidikan memiliki peran yang sangat strategis. Landasan dalam mengembangkan kurikulum sangat diperlukan tidak hanya bagi para penyusun kurikulum (makro) atau kurikulum tertulis yang disebut sebagai kurikulum ideal, tetapi juga harus dapat dipahami dan dijadikan dasar pertimbangan bagi para pelaksana kurikulum (mikro) yaitu para pengawas pendidikan, guru serta pihakpihak lain yang terlibat dalam tugas-tugas pengelolaan pendidikan, sebagai bahan untuk dijadikan instrument dalam melaksanakan pembinaan terhadap implementasi kurikulum di setiap jenis dan jenjang pendidikan (Aziz, 2018: 44).

Perencanaan kurikulum di sekolah dasar Islam terpadu dilaksanakan secara cermat dan teliti untuk memenuhi kebutuhan siswa. Sekolah menyediakan fasilitas sarana dan prasarana pembelajaran 
yang memadai bagi peserta didik, program sekolah dikemas secara menarik, sistem pembelajaran yang terpadu dengan pendidikan agama untuk pembinaan akhlak karimah atau pembinaan karakter siswa. Perencanaan kurikulum dilaksanakan dalam bentuk atau kegiatan program sekolah, seperti kegiatan outbond, pramuka, market day, program tahfizd Al-Qur'an, dan kegiatan ekstrakulikuler lainnya. Pelaksanaan kurikulum SMAIT Ukhuwah berjalan dengan baik, hal ini terlihat dari kedisiplinan pelaksanaan pembelajaran dan kegiatan sehari-hari. Siswa mendapatkan pelayanan yang baik dari sekolah, adanya guru kelas dan wali kelas di setiap kelas membuktikan adanya perhatian yang baik terhadap siswa. Budaya sekolah yang Islami terlihat dari aktivitas sehari-hari siswa.

2) Sumber Daya Manusia (SDM)

\begin{tabular}{lrr}
\multicolumn{2}{c}{ Meningkatkan } & kualitas \\
sumber daya & manusia \\
terutama dalam & bidang \\
pendidikan mutlak & adanya. \\
Sekolah memiliki & fungsi \\
sebagai sarana atau wahana & wroses edukasi bagi & peserta \\
didik, sekolah sebagai sarana & salisasi antara \\
proses sosialisasi & dan seluruh \\
peserta didik dan & komponen sekolah, dan
\end{tabular}
sekolah sebagai sarana proses transformasi keilmuan yang memiliki orientasi duniawi dan ukhrawi bagi peserta didik. Berdasarkan pemaparan Ustadzah Sri Astuti, S.Pd, faktor guru dan sumber daya manusia merupakan faktor pendukung dalam penerapan full day school dalam pembinaan aklakul karimah siswa SMAIT Ukhuwah Banjarmasin terutama ustadzustadzah yang berkompetensi. Para pendidik atau tenaga pengajar di SMAIT Ukhuwah Banjarmasin adalah alumni perguruan tinggi negeri dan swasta yang mempunyai motivasi tinggi dalam memajukan pendidikan di sekolah. Para pendidik harus 
memiliki kualitas pengetahuan dan pemahaman Islam yang baik, berakhlak mulia, cakap dan terampil serta memahami bagaimana perkembangan peserta didik.

3) Sarana dan Prasarana

Kualitas pendidikan yang baik di dukung oleh tersedianya sarana dan prasarana yang memadai. Mengingat pentingnya sarana prasarana dalam kegiatan pembelajaran secara otomatis sekolah, guru dan peserta didik akan terlibat secara langsung. Peserta didik akan terbantu dengan adanya dukungan sarana prasarana dalam proses pembelajaran. Tingkat pengetahuan dan pemahaman peserta didik berbeda-beda. Ada peserta didik yang memiliki tingkat kecerdasan yang baik dan ada juga peserta didik yang memiliki tingkat kecerdasan yang kurang sehingga penggunaan sarana prasarana dapat membantu mereka dalam mengikuti proses pembelajaran. Bagi guru dengan adanya sarana prasarana proses pembelajaran lebih variatif, menarik dan bermakna, sedangkan pihak sekolah memiliki kewajiban sebagai pihak yang bertanggung jawab terhadap penyediaan dan pengelolaan seluruh kegiatan yang dilaksanakan. Selain menyediakan pihak sekolah juga menjaga dan memelihara sarana prasarana yang dimilki agar tetap terawat dengan baik.

Fasilitas sarana prasarana yang disediakan SMAIT Ukhuwah Banjarmasin, sebagai sekolah yang menerapkan sistem full day school dikatakan cukup mendukung serta dimanfaatkan dengan baik dalam rangka kegiatan belajar mengajar dan pembinaan akhlakul karimah siswa SMAIT Ukhuwah Banjarmasin. Sarana prasarana di SMAIT terdiri dari ruang kelas yang nyaman, kamar mandi/wc, lapangan, GOR, tempat parkir yang luas, kelengkapan sound system, LCD proyektor, dan sebagainya. Setiap ada kegiatan, fasilitas yang diperlukan sudah ada sehingga 
membuat peserta didik betah dan nyaman berada di sekolah dan semangat dalam menjalani kegiatan belajar mengajar di sekolah.

4) Orang Tua yang Mendukung

Orangtua memiliki peran yang sangat penting dalam pertumbuhan dan perkembangan anak. Menurut Naim (2012: 164), sikap yang seharusnya dimiliki oleh orangtua adalah memberikan kesempatan yang luas bagi anak untuk berproses dan berkembang. Sehingga dukungan dan aspresiasi yang diberikan orangtua kepada anak sangatlah dibutuhkan untuk mengembangkan potensi dan karakter anak agar menjadi lebih baik lagi. Orang tua siswa sangat mendukung terhadap penerapan full day school dalam pembinaan akhlakul karimah siswa di SMAIT Ukhuwah Banjarmasin, hal itu terbukti dengan adanya interaksi aktif dan diwujudkan dengan adanya kerjasama yang baik antara orang tua siswa dengan pihak sekolah. Salah satu wujud kerja sama tersebut yaitu kesediaan dan kesiapan orang tua siswa mendukung setiap program yang diselenggarakan oleh pihak sekolah untuk kegiatan siswa. Orang tua juga diharapkan agar selalu aktif menjalin komunikasi dengan guru terkait perkembangan siswa melalui SMS/WA dan telpon.

b. Faktor Penghambat

\section{1) Faktor Lingkungan}

Lingkungan adalah suatu tempat dimana manusia saling membutuhkan dan saling berinterkasi antar manusia satu dengan manusia lainnya. Faktor penghambat dalam pembinaan akhlakul karimah siswa di SMAIT Ukhuwah Banjarmasin adalah kesadaran siswa dan faktor lingkungan sosial diantaranya teman bermain, tetangga dan masyarakat dimana siswa itu tinggal. Lingkungan sosial sangat berpengaruh dalam pembinaan akhlakul karimah siswa baik itu pengaruh baik maupun pengaruh buruk terhadap siswa, tergantung bagaimana anak memilih 
pergaulan dan teman yang baik.

2) Dana

Sebagaimana

yang

disampaikan oleh Kepala

SMAIT

Ukhuwah

Banjarmaasin, salah satu faktor yang menjadi penghambat dalam penerapan full day school adalah permasalahan pada pendanaan yang sering terlambat diberikan kepada pihak sekolah. Bantuan dari pemerintah pusat seperti BOS adalah hanya mampu membantu sebagian biaya operasional sekolah, tidak lebih dari seperlima dari dana total operasional sekolah. Masih sangat banyak diperlukan dukungan dana dari sumber lainnya.

\section{KESIMPULAN}

1. Penerapan full day school dalam pembinaan akhlakul karimah siswa di SMAIT Ukhuwah Banjarmasin melalui kegiatan intrakurikuler serta ekstrakurikuler. a. Pembentukan akhlak siswa melalui kegiatan intrakurikuler, pertama melalui Kegiatan Belajar Mengajar (KBM) dengan mengkaitkan materi pembelajaran dengan nilainilai Islam, pembiasaan dalam kegiatan positif, keteladanan dari ustadz/ah, dan pemberian nasehat baik pada saat KBM berlangsung maupun pada saat waktu istirahat. Kedua, Bina Pribadi Islami (BPI) dalam kegiatan ini ustadz/ustadzah selalu berusaha memberikan pembinaan terhadap akhlak siswa secara maksimal dengan melakukan pemantauan dan pengawasan terhadap siswa yang menjadi bimbingannya baik ketika siswa berada di sekolah maupun di luar sekolah, sehingga hasil pembinaan dan pembentukan akhlakul karimah siswa diharapkan dapat berjalan secara optimal dan hasilnya menjadi maksimal. 
b. Pembentukan akhlak siswa melalui kegiatan Ekstrakurikuler, pertama Pramuka kegiatan ekstra ini dikemas dalam kegiatan kemah pramuka yang dilaksanakan dan dirancang pembina dengan kegiatan positif yang bertujuan untuk membentuk akhlak siswa. Kegiatan-kegiatan tersebut tidak terlepas dari ruang lingkup pembahasan tentang akhlak yang terdiri dari akhlak atau hubungan manusia dengan Allah, hubungan manusia dengan sesama manusia dan hubungan manusia dengan lingkungan. Kedua, Olahraga dan Seni, kegiatan olahraga seperti futsal dan tari tetap mengedepankan akhlak yang mulia kepada Allah yaitu memperhatikan adab berpakaian yang sesuai dengan perintah agama Islam.

Ketiga, Kegiatan Tarhib Ramadhan, dalam kegiatan ini siswa diajak bersosialisasi dengan masyarakat sekitar sekolah dengan berbagi kepada sesama dan melakukan pembersihan masjid dan musola. Hal ini menunjukkan bahwa dalam kegiatan tarhib Ramadhan sekolah menanamkan akhlak tidak hanya akhlak kepada sesama melainkan juga terhadap akhlak kepada lingkungan.

2. Faktor pendukung dan penghambat penerapan full day school dalam pembinaan akhlakul karimah siswa di SMAIT Ukhuwah Banjarmasin meliputi:

a. Faktor pendukung: 1) Kurikulum yang sesuai dengan integrasi nilai-nilai keislaman; 2) Sumber daya manusia yang berkualitas; 3) Sarana prasarana yang memadai; 4) Dukungan orang tua siswa.

b. Faktor penghambat: 1) Faktor lingkungan siswa, 2) Faktor pendanaan.

\section{DAFTAR PUSTAKA}


Arief, Armai. 2002. Pengantar Ilmu

Islam Ta`im Volume 15 dan Metodologi Pendidikan Islam. Jakarta: Ciputat Press

Arifin, Zainal. 2012. Pengembangan Manajemen Mutu Kurikulum Pendidikan Islam. Jogjakara: Diva Press

Aziz, Rosmiaty. 2018. Implementasi Pengembangan Kurikulum. Volume VII Nomor 1 JanuariJuni. Fakultas Tarbiyah dan Keguruan UIN Alauddin Makassar

Daryanto. 2013. Implementasi Pendidikan Karakter di Sekolah. Yogyakarta: Gava Media

Hidayat, Nurul. 2015. Metode Keteladanan Dalam Pendidikan Islam. Jurnal Ta`allum, Volume 3 Nomor 2 November

Mappanganro. 1996. Implementasi Pendidikan Islam di Sekolah Cet 1. Ujung Pandang: Yayasan Ahkam

Muhaimin. 2009. Pengantar Kurikulum PAI. Jakarta: Raja Grafindo Persada

Manan, Syaepul. 2017. Pembinaan Akhlak Mulia Melalui Keteladanan dan Pembisaan. Jurnal Pendidikan Agama 
Al-Mudarris: Jurnal Ilmiah Pendidikan Islam

p-ISSN: 2622-1993

Vol. 2, No. 1, Mei 2019, pp. 1-17

e-ISSN: 2622-1586 